\title{
A REDISCUSSÃO DO RISCO NOS PROCESSOS DE REASSENTAMENTO E REALOCAÇÃO DE MORADIAS NO BRASIL $O$ caso da Faixa de Domínio Ferroviário sob a experiência das comunidades da Guarita e Passo da Pátria, Natal, RN, Brasil
}

\section{REDISCUSSION OF RISK IN RESETTLEMENT AND REALOCATION OF HOUSING IN BRAZIL}

The case of the Railway Domain strip under the experience of the Guarita and Passo da Pátria communities, Natal, RN, Brazil

\section{A. Maria Caroline F. Diógenes \& B. Samara S. C. da Silva}

Universidade Federal do Rio Grande do Norte, Brasil.

carolfarkat@yahoo.com.br

samarasayo@gmail.com

\section{RESUMO}

O risco vem servindo de justificativa para intervenções urbanas e habitacionais desde o princípio das ações do estado sobre a temática da moradia, influenciando diferentes posturas no tempo. Com isso, o presente estudo tem como objetivo apresentar, de forma sucinta, a abordagem estabelecida historicamente sobre à moradia em situação de risco no Brasil, aproximando-se especificamente à questão das construções localizadas em áreas de Domínio Ferroviário em duas comunidades do município de Natal (RN). Em termos metodológicos, o artigo faz um estudo de caso nas Comunidades da Guarita e do Passo da Pátria, inseridas no território em questão, a fim de se levantar qual a percepção e o posicionamento das comunidades sobre a problemática. Chegando a conclusão que ações pautadas somente sobre a questão da habitação e sua infraestrutura não são suficientes, uma vez que as relações sociais devem ser observadas neste processo.

Palavras-chave: risco, moradia, domínio ferroviário.

Linha de Investigação: 3- Dinâmicas Urbanas - Assentamentos Precários

\section{ABSTRACT}

The risk has been serving as a justification for urban and housing interventions since the beginning of the state's actions on the subject of housing, influencing different attitudes over time. With this, the present study aims to present, in a succinct way, the historically established approach to housing at risk in Brazil, specifically approaching the issue of constructions located in areas of Railway Domain in two communities of Natal, Rio Grande do Norte. In methodological terms, the article makes a case study in the Communities Guarita and Passo da Pátria, inserted in the territory in question, in order to raise what is the perception and the position of the communities on the problem. Coming to the 


\section{SÃO PAULO15 - 17 LISBOA 25 26 JUN 2020 \\ Seminário Internacional de

conclusion that actions based only on housing problems and their infrastructure are not enough, since social relations must be observed in this process.

Keywords: risk, housing, railroad domain.

Research line: 3- Urban Dynamics - Precarious Settlements

\section{Introdução}

O risco vem servindo de justificativa para dar caráter prioritário a algumas intervenções urbanas e habitacionais desde o princípio da ação do estado na questão habitacional, influenciando diferentes posturas no tempo. Nesse conjunto se inserem um contingente populacional que se instalou em áreas desprestigiadas tais como: encostas, faixas de domínio de ferrovia ou rodovia, entre outras situações de risco, que estão suscetíveis a processos de relocação e por serem relegados à margem do processo de produção habitacional regular. Estes locais acabaram por constituir áreas com potencial de ocupação, visto que eram livres de ações de reintegração de posse ou fiscalização estatal devido à falta de interesse do mercado imobiliário à época, ou carência institucional para fiscalização respectivamente.

Um modelo próprio da ocupação informal brasileira já repetidamente conhecido. A diferença de futuro em cada caso está na decisão por cada uma das alternativas de intervenção mencionadas, a qual passa pela compreensão do técnico sobre o risco incidindo na postura de condução dos projetos habitacionais. Tais decisões de gestão, no Brasil em princípio, foram influenciadas pela ideologia higienista, passando à técnica objetivista até evoluir para a gestão democrática orientada pelas políticas Urbanas e Habitacionais condizentes com o Estatuto das Cidades.

É pertinente iniciar sobre o Histórico dos processos de remoção e relocação no Brasil (BONDUK,1998) conhecendo algo na esfera internacional (HALL, 1988). Para depois situar o as novas discussões sobre o risco na perspectiva das comunidades (VARGAS, 2006), considerando o atual cenário das Políticas Urbanas do Brasil (MINISTÉRIO DAS CIDADES, 2004). Como fechamento tem-se a apresentação da problemática das OFDF exemplificada no caso da Comunidade Guarita e Passo da Pátria, ambas em Natal/RN.

\section{Notas Históricas dos Projetos Habitacionais no Brasil e os processos deslocamento de famílias.}

Anterior ao início do séc. XX, o estado adotava uma postura liberal e não intervia na produção habitacional deixando essa atividade ao sabor do mercado. Mas no começo do séc. XX houve pressões sociais para que o problema da provisão habitacional tornar-se uma questão de estado. Os empresários das principais capitais brasileiras como São Paulo e Rio Janeiro tinham motivos para desejar a intervenção do estado nessa questão. Precisavam que seu empregado arranjasse uma morada digna para repousar e produzir satisfatoriamente sem precisar aumentar seus salários. A péssima qualidade da morada do trabalhador somado a exploração do seu trabalho diário poderia conduzi-los a um estado de revolta iminente (BONDUK, 1998). Além disso, as elites brasileiras desejavam reconstruir a cidade conferindo ares de modernidade, assemelhando-se às cidades 


\section{SÃOPAULO15 $17 \cdot$ LISBOA $25 \sim 26$ JUN 2020 \\ Seminário Internacional de \\ Seminario Internacional de

europeias. Tal desejo assumia uma justificativa desenvolvimentista escondendo a real intenção de afastar os cortiços e a classe pobre dos grandes centros urbanos.

No âmbito internacional, já se discutia a necessidade de intervenção estatal nas condições de moradia do trabalhador, também nascidas na Europa e na América por motivos semelhantes aos elencados pelas elites brasileiras (HALL, 1988, p.42)

Nesse contexto nacional e internacional a ação inicial dos gestores brasileiros foi promover a higienização das vilas, cortiços e todos os tipos de moradia da classe trabalhadora. Segundo Bonduk (1998, p.31, grifo nosso) "Os agentes da ordem sanitária não hesitaram em invadir casas, remover moradores (doentes ou não), desinfetar móveis e objetos pessoais, demolir e queimar casebres, isolar quarteirões, prender suspeitos, atacar focos". A intenção dos higienistas, era impor a prática de educação sanitária, como se esta fosse uma questão de educação e não um efeito da condição econômica dos trabalhadores.

Porém as medidas iniciais tomadas pelo estado brasileiro foram pontuais e não tinham a intenção de atuar na solução do problema. Os higienistas optaram pela desinfecção das casas com doentes, ao invés de pensar em alternativas para resolver o problema de forma geral. Quando a limpeza não era suficiente, em casos extremos, a família era removida e a unidade habitacional demolida. Esse tipo de ação é conhecida como remoção, nela ocorre à retirada da família do local precário de forma arbitrária sob justificativas técnicas. Essa é a forma clássica em que os trabalhadores de baixa renda foram sendo deslocados para as periferias.

Posteriormente, o entendimento de que o estado deveria intervir na questão habitacional fomentou em 1940 processos de retirada de famílias configurando os processos de relocação. Tal processo é distinto das remoções promovidas no início do sec. XX, uma vez que a remoção retira as famílias sem conceder-Ihes alternativa de moradia. Nessa época a produção habitacional era dada pelos Institutos de Aposentadorias e Pensões (IAPs), a Fundação da Casa Popular entre outros, que surgiram para servir as camadas populares. No entanto, as primeiras propostas habitacionais, apesar de fornecerem alternativa de moradia à classe trabalhadora, muitas delas traziam consigo a intenção de transferi-los para a periferia. Esta intenção pode ser compreendida no espaço intra-urbano das cidades, uma vez que contribuiu para a formação de uma hierarquia de direito de Uso do Solo Urbano conforme o poder aquisitivo de cada indivíduo (VILLAÇA,1998).

O risco, nestes casos, assumiu a função de justificar as ações de intervenção do estado na morada da população pobre, no começo das iniciativas habitacionais em São Paulo (BONDUK, 1998, p.236).

\section{Os processos de relocação e a discussão do risco sob considerações do atual cenário das políticas Urbanas e Habitacionais do Brasil.}

Os processos de relocação passam a assumir novos direcionamentos na constituição de 1988, devido a solicitações de diversas camadas sociais pelo direito à cidade. O movimento de Reforma Urbana consegue inserir, através de emenda popular, os art.182 e 183 na nova constituição. Estes artigos regulamentados pelo Estatuto da Cidade ${ }^{1}$, autorizam a regularização fundiária dos assentamentos

\footnotetext{
${ }^{1}$ Lei N. 10257/01, com destaque para a Medida Provisória 2.220 de 2001.
} 


\section{SÃO PAULO15 - 17 LISBOA $25 \sim 26$ JUN 2020 \\ Seminário Internacional de \\ Investigação em Urbanismo \\ Seminario Internacional de \\ Investigación en Urbanismo

precários localizados em propriedades públicas, desde que seja para proteger o direito à moradia à população de baixa renda resguardada as normas de uso e ocupação e legislações ambientais. A partir disso, se compreende que a propriedade da terra possui função social e às populações consolidadas nesses assentamentos de risco passam a ter maior condição de lutar por direito à cidade, a moradia digna e a gestão democrática².

Nessa nova perspectiva, a relocação ${ }^{3}$ passa a ser orientada pelo Ministério das Cidades como última solução para urbanização de assentamentos precários. A preferência, a partir disso, é dada ao reassentamento 4 (MINISTÉRIO DAS CIDADES, 2007-2010) das famílias, visto que a permanência dos residentes desses assentamentos em suas localidades ou áreas próximas garante-lhes o Direito à Cidade. Pertinente a essas mudanças, as discussões voltaram-se sobre a definição do risco em assentamentos precários e as técnicas utilizadas para identificação dele. Isto, pelas críticas à análise objetivista do risco, a qual se fundamenta num estudo quantitativo e descritivo sem ponderar outros fatores como, o contexto sócio-econômico em que foram inseridas essas comunidades.

Segundo Vargas (2006, p.60) na década de 60 o estudo do risco se desenvolveu em várias disciplinas como toxicologia, epidemiologia, psicologia e engenharia. Todas sob uma proposta de análise quantitativa e descritiva, a fim de controlar o conhecimento dos fenômenos que geram os riscos. Já na década de 1970 e 80 essa metodologia de leitura do risco foi amplamente criticada em virtude da incerteza dos laudos nas suas conclusões. Tal situação ocorria pela carência de instrumentos de precisão na medição, o que acarreta a definição do risco pela experiência profissional (VARGAS, 2006, p.61)

A falta de certeza na definição do risco é algo que deveria impor aos profissionais que fossem feitas ponderações, buscando aliar a compreensão de outros aspectos, antes de decretar a retirada de famílias de assentamentos precários como única alternativa.

Uma dessas metodologias de análise do risco, a qual pondera outros aspectos, seria dada através do envolvimento da população afetada na avaliação do risco e construção do diagnóstico local. Quando o profissional opta por ouvir os moradores dos assentamentos de risco ele tem a possibilidade de analisar a situação sob outras óticas e indagações diferentes das suas. Dessa forma, a proposta metodológica modifica-se de uma descrição técnica objetivista para um estudo participativo.

No entanto, a metodologia participativa enfrenta dificuldades para sua efetivação, tendo em vista ser pouco utilizada na prática, mesmo a gestão democrática sendo diretriz da Política Nacional de Habitação (2004).

Segundo Vargas $(2006$, p.63) “... a recategorização do que é risco associa-se aos esforços de permanência no lugar para os fins de garantia da posse dos ativos sociais, configurando uma

2 A moradia digna e a gestão democrática atualmente são diretrizes da Política Nacional de Habitação publicada em 2004.

${ }^{3}$ Remanejamento de famílias residentes em áreas não consolidáveis para áreas afastadas da sua localidade original, periferias.

${ }^{4}$ Remanejamento de famílias de famílias residentes em áreas não consolidáveis para áreas próximas da sua localidade original. 


\section{SÃO PAULO15 - 17 LISBOA $25 \sim 26$ JUN 2020

resistência a noção técnica dominante do risco." Assim, há uma relativização do risco, buscando reavaliá-lo sob a ótica de quem deseja a permanência na área.

O interesse de permanência sobressai por diversos fatores. Um deles é o desejo de continuidade das relações de vizinhança, da manutenção da vida cotidiana. Quando em áreas centrais, esse desejo se acentua pela proximidade e acesso aos serviços públicos, melhores condições de mobilidade, proximidade aos locais de emprego formais ou informais. Em áreas de risco consolidadas pelo longo período de permanência, há uma maior possibilidade dos barracos terem se tornado moradias de alvenaria melhoradas com o tempo.

Contudo, o motivo mais forte, que leva ao receio de mudanças, quando apresentadas as propostas de intervenção urbana, é o medo de voltar a não ter onde morar ou de sofrer privações em decorrência do retorno ao pagamento de aluguel. Tais apreensões são mais temidas pelos moradores do que a exposição ao risco. Principalmente, quando o risco se configura apenas como uma ameaça futura (VARGAS, 2006, p.69).

No processo de contestação da definição objetivista do risco, a população, pressionada pelas circunstâncias, sente a desconsideração dos outros aspectos como contexto histórico, social e econômico delas. Mesmo ponderando esses outros aspectos pertinentes a definição do risco, se estas informações não fundamentarem as soluções projetuais, o processo participativo não será efetivado permanecendo os entraves.

Tais cuidados durante as negociações são importantes em virtude da descrença com relação às ações do governo brasileiro em função dos históricos das remoções. Além disso, as alternativas de estabilização do risco para viabilizar a permanência da comunidade na área são, comumente, mais onerosas e, portanto, facilmente descartadas pelos gestores públicos (VARGAS, 2006, p.61).

Contudo, mesmo com o Estatuto das Cidades e a orientação pela preferência dos reassentamentos como garantia do Direito à Cidade ainda se evidencia o modelo periférico identificado por Villaça.

Em Natal, o Projeto habitacional Planalto II no período 2006-2007 inserido no Programa de Aceleração do Crescimento (PAC), reassentou seis assentamentos: Via Sul, Alagamar, Pião, DETRAN, 8 de outubro, Luiz Gonzaga. A alternativa adotada pelo Município retirou famílias dos bairros situados nas regiões leste e sul de Natal para a região Oeste, mais precisamente para o bairro Guarapes. Constatase nesse procedimento que houve um deslocamento de famílias de áreas bem estruturadas da cidade para uma região que apresenta fragilidades quanto à inserção urbana, notadamente quanto ao acesso ao transporte público e a equipamentos.

A escolha da maioria dos assentamentos não se deu por critérios técnicos pré-definidos, a exemplo de aspectos socioeconômicos e urbanísticos ou situações de risco. Houve ausência de critérios que levassem em consideração o tempo de permanência dos assentamentos nos seus respectivos locais de origem analisando a condição real do assentamento (DIÓGENES, 2014). Além disso, atualmente, no âmbito do Programa Minha Casa Minha Vida (PMCMV) Ferreira (2016) identificou a concentração de projetos de HIS na periferia dessas zonas identificando a lógica de mercado de menor preço. 


\section{SÃOPAULO15 $17 \cdot$ LISBOA $25 \sim 26$ JUN 2020

\section{Inserção das Ocupações e Faixa de Domínio de Ferrovias (OFDF) e os processos brasileiros de relocação ou reassentamento}

No caso das Ocupações em Área de Domínio de Ferrovias (OFDF), o restabelecimento da Faixa de Domínio de Ferrovia (FDF) é imperativa. Segundo classificação do Ministério das Cidades (Mcidades) as OFDF são áreas não consolidáveis por se tratar de terreno ocupado e identificado como impróprio, haja vista ser uma área não edificante (BRASIL, 2010).

Na verdade, as OADF estão dentro de duas faixas não edificáveis, as quais são contíguas e devem ser bem reconhecidas. Imediatamente contígua ao trilho existe a Faixa de Domínio de Ferrovia ${ }^{5}$ - FDF - e depois sua faixa não edificante, conforme a Lei 13.913/2019 (Figura 1).
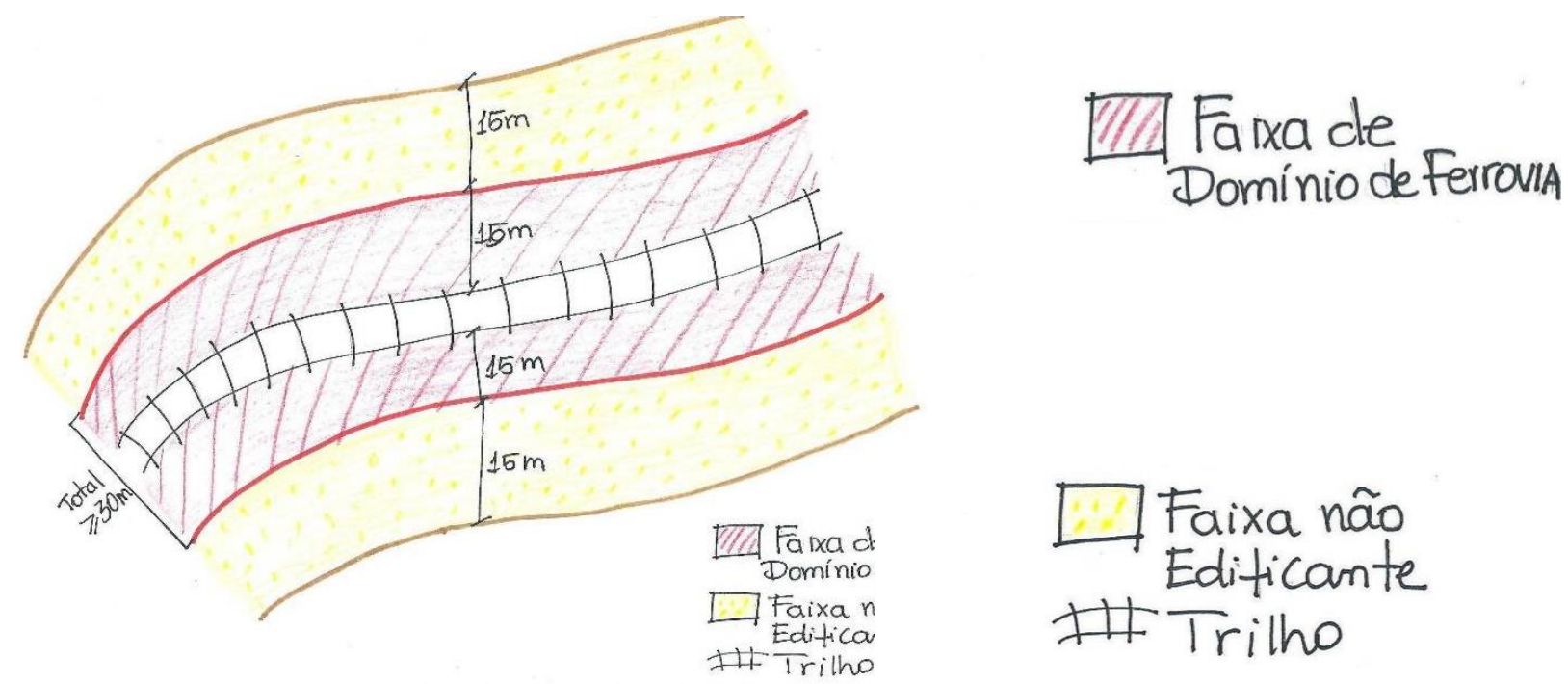

=igura 1: Croqui esquemático da Faixa de Domínio de Ferrovia e sua não edificante. Fonte: própria(2012).

No entanto, com o processo de decadência da antiga Rede Ferroviária Federal SA (RFFSA) no final da década de 80, agravado durante a década de 90 quando a malha ferroviária de cargas entrou em processo de liquidação, culminou na criação da Companhia Brasileira de Trens Urbanos (CBTU) de Natal apenas para o transporte de passageiros em 1984 (CBTU, 1997). Logo, infere-se que, durante esse processo, houve incapacidade de fiscalização da FDF tanto das instituições ligadas a ferrovia quanto do município. Isto, aliado ao crescimento acelerado da cidade, contribuiu para a ocupação das FDF e sua faixa não edificante em Natal.

Por estas razões, evidencia-se a maioria das unidades habitacionais em FDF como sendo provenientes da época de decadência da antiga RFFSA. Com esse tempo de permanência, já se estabilizaram na área apresentando identificação e relação histórica com a ferrovia. Por isso, tratamse de assentamentos consolidados, mesmo que irregularmente.

\footnotetext{
${ }^{5}$ Definida pelas Normas Técnicas para as Estradas de Ferro Brasileiras, aprovada pela resolução 43/66, de 01/04/66, do Conselho Ferroviário Nacional - CFN.
} 


\section{SÃOPAULO15 $217 \cdot$ LISBOA $25 \sim 26$ JUN 2020 \\ Seminário Internacional de \\ Seminario Internacional de

Dessa forma, o contexto de intervenção urbana assume uma série de características muito próprias nessas áreas, conforme sintetizado abaixo:

- Histórico relacionado com a ferrovia;

- Populações de baixa renda com melhores condições de habitabilidade na estrutura física da residência;

- Irregularidade Jurídica da posse com necessidade imperativa legal de relocação ou reassentamento;

Neste sentido, a discussão comunitária configura-se como escolha metodológica mais apropriada para promover a relocação, a fim de alcançar a adesão da comunidade à proposta, e viabilizar a execução. Por outro lado a retirada por ordem judicial é uma escolha de ação demorada sem o acordo com os interessados. Contudo vem se observando como escolha recorrente na experiência brasileira, mesmo que implique no risco de engessamento da proposta e aumento do investimento público com a manutenção da gestão por tempo indeterminado.

Uma das dificuldades relacionadas aos casos específicos de relocação das (OFDF) pode ser provocada pela diferença de tamanho entre a unidade habitacional e o lote ofertado pelo programa habitacional brasileiro e as consolidadas na (FDF). Quanto aos materiais de acabamento nas OFDF, podem-se encontrar casas com cerâmica, por exemplo, devido a investimentos alcançados ao longo dos anos.

Outra dificuldade, que teria implicações durante a negociação, pode ser gerada pela não percepção ou diminuição do risco na ótica comunitária. Já que a FDF seria destinada aos descarrilamentos e a frequência de acidentes é maior nas passagens de nível irregulares, clandestinas, ou mesmo as regulares que possuem problemas com a manutenção da sinalização. Felizmente, esse tipo de acidente não é freqüente. Segundo matéria do jornal local Tribuna do Norte, acidentes por descarrilamento não são frequentes tanto quanto por abalroamentos ou atropelamentos (TRIBUNA DO NORTE, 2008). Diante disso, a comunidade residente na FDF pode achar viável a permanência e regularização da posse. No entanto, um acidente por descarrilamento possui um potencial de gravidade maior.

Contudo, mesmo diante das dificuldades inerentes aos processos de relocação e acentuadas nos casos das FDF pelos motivos aqui mencionados, faz-se necessário à intervenção do poder público nessas áreas. Isto, não apenas para solucionar o problema habitacional, como também para desenvolver o Transporte Ferroviário Urbano como alternativa de incremento à mobilidade nos grandes centros urbanos.

\section{Apontamentos sobre processos de intervenções em OFDF mais recentes no Brasil}

Ao se empreender pesquisas a respeito dos casos de ocupações ou invasões na faixa compreendida como Domínio Ferroviário, utilizando como ferramenta de levantamento as demandas judiciais que fazem referência a estes territórios no Brasil, verificou-se um extenso número de ações jurídicas oriundas de diversas localidades do país. As ações de reintegração de posse são as mais comuns após o abandono dos terrenos de FDF e sua consequente invasão ou ocupação. 


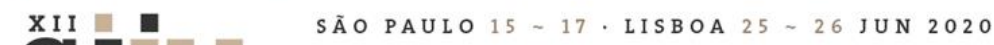

Tentativas de restabelecimento de FDF também foram encontradas em Fortaleza (CE), onde, acordo com Mota (2007), foram empreendidas algumas realocações de moradores para conjuntos habitacionais financiados pela prefeitura municipal, como também a instalação de muros e cercas separando as áreas de domínio dos espaços de moradia e fluxo de pessoas e veículos. Porém constata-se que as ações ainda se mostram pontuais e não atingem toda extensão dos trilhos afetada pela problemática.

O município de Natal apresenta a problemática de ocupações na FDF e sua área não edificável por praticamente toda a extensão do modal, no qual de acordo com levantamento da prefeitura municipal (2016) existiam cerca de 1.714 construções somente na FDF.

\section{A Guarita}

A comunidade Guarita formada na primeira fase de expansão periférica da Natal/RN, entre 1950 e 1960, ocupando a área contígua entre o Rio Potengi e a linha férrea (figura 2).

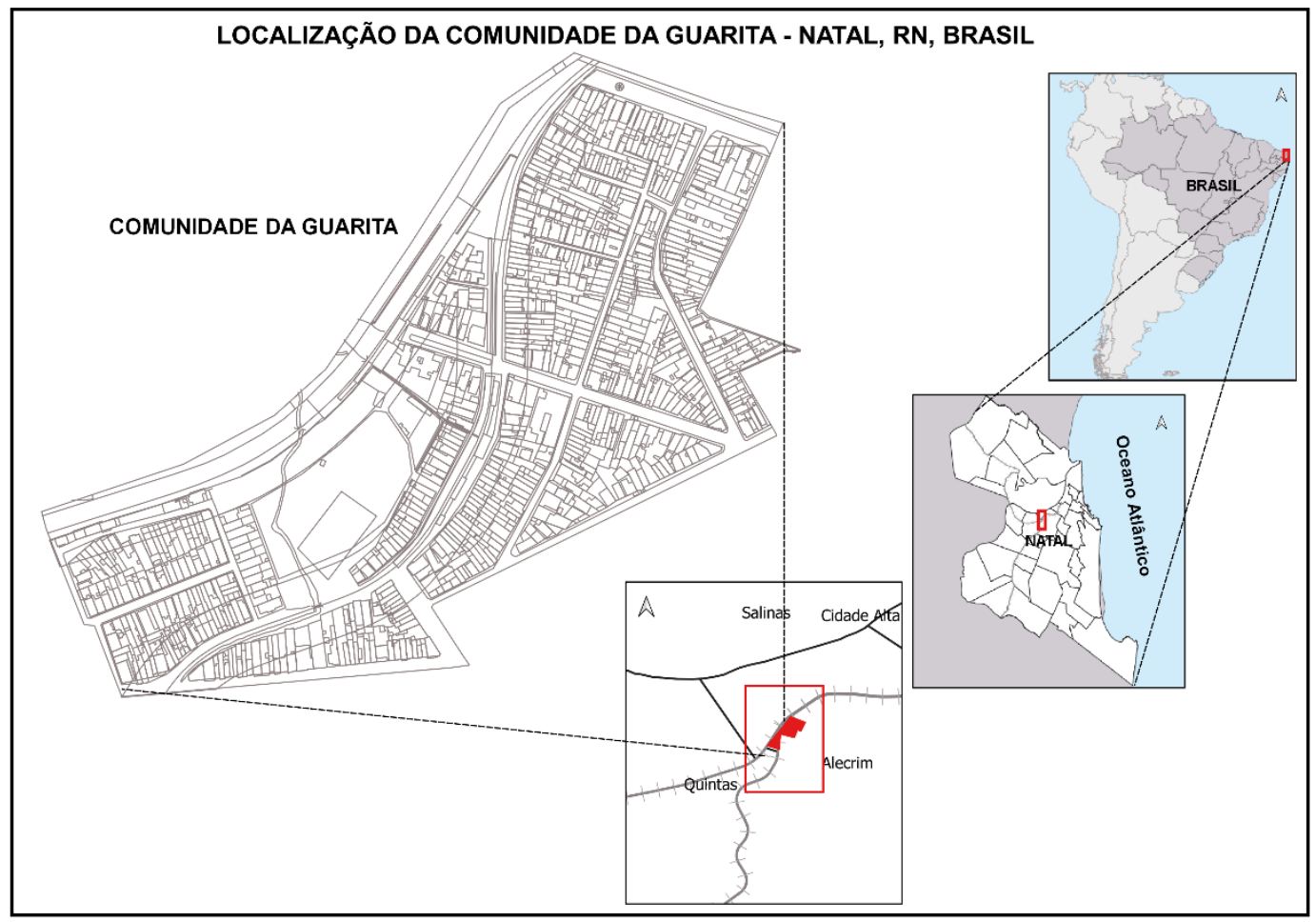

Figura 2: Delimitação da Guarita entre os bairros do Alecrim e Quintas. Elaboração das autoras (2020) 


\section{SÃOPAULO15 17 LISBOA $25 \sim 26$ JUN 2020 \\ Seminário Internacional de \\ Seminario Internacional de Investigação em Urbanismo Investigación en Urbanismo}

Nela foram identificadas, características morfológicas de ocupações irregulares como: concentração de habitações por quadra, vilas, lotes pequenos e despadronizados. Além de uma formação não planejada a localidade contempla ocupações com alta densidade populacional próprias de populações com baixa renda (ALCÂNTARA, 2008). Pelo tempo de permanência as OFDF da guarita já garantiram o direito de moradia e a cidade de acordo com o Estatuto das Cidades.

Verifica-se a possibilidade da permanência dos residentes na FDF na localidade, graças a presença de uma área livre capaz de abrigar ações de intervenção urbana e promover a requalificação da localidade. Em 2009, Diógenes deu continuidade aos estudos da pesquisa A Guarita e o Trem e elaborou um Plano de Estruturação Urbana junto com a comunidade.

No entanto, apesar da importância do projeto não apenas para a comunidade, como para toda a Região Metropolitana de Natal com o desenvolvimento do Transporte Ferroviário, muitos são os motivos que podem ser relacionados pela comunidade para questionar a retirada das famílias da FDF. Isto considerando que o processo de relocação deva ser conduzido com a participação da comunidade com inserção dos argumentos comunitários na análise do risco (VARGAS, 2006).

Um dos entraves esperados durante a discussão comunitária é decidir de para quem serão destinadas às UH da proposta habitacional, considerando que o déficit na Guarita não é apenas quantitativo, mas também qualitativo. Isto, porque os moradores reconhecem a carência habitacional na comunidade não apenas para o contingente da FDF e sua não edificante, mas também para os casos de co-habitação e a presença de vilas precárias. Assim eles podem eleger como prioridade a provisão habitacional para as pessoas que moram de aluguel em vilas insalubres, ao invés de retirar uma residência de melhor qualidade, sem o ônus do aluguel, da posse de um residente na FDF (DIÓGENES, 2009).

Outro fator, esperado como complicador durante as negociações, é a inegável comparação entre a situação das OFDF da Guarita com o restante das ocupações ao longo da malha ferroviária de Natal. Na extensão da FDF no Bairro das Quintas, é possível encontrar casos em situação de risco pior do que o encontrado na Guarita (Figura 5 a Figura 6). Além de mais distante do trilho, as OFDF da Guarita possuem uma rua estreita e muro de proteção entre as UH e o trilho, mesmo estando dentro da FDF.

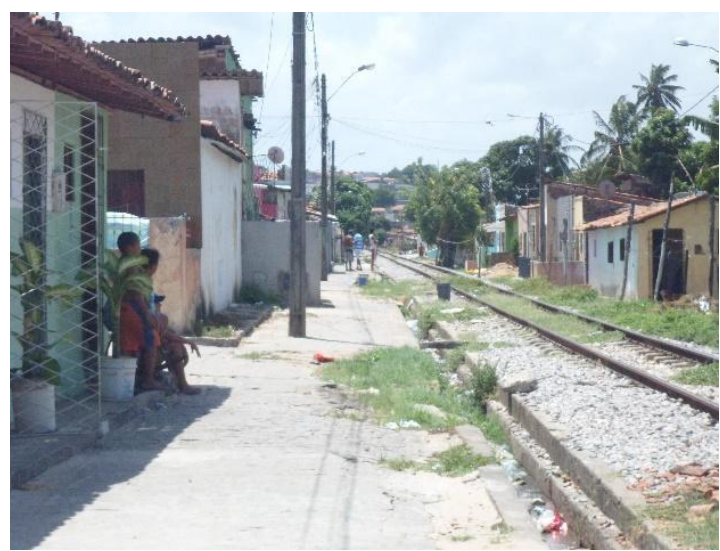

=igura 3: OFDF no Bairro das Quintas em Natal/RN. Fonte: Jiógenes(2012)

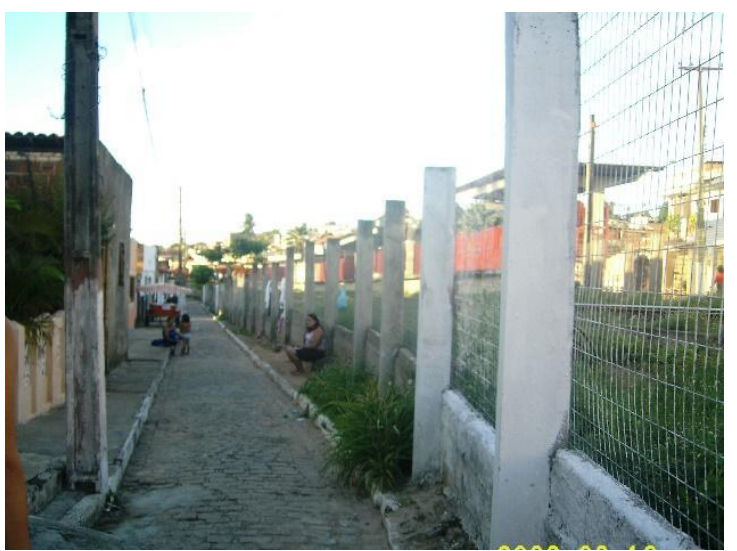

تigura 4: OFDF na Comunidade Guarita em Natal/RN. Fonte: Jiógenes(2012) 


\section{SÃO PAULO15 17 LISBOA $25 \sim 26$ JUN 2020 \\ Seminário Internacional de \\ Seminario Internacional de Investigação em Urbanismo Investigación en Urbanismo}

Assim, em processos de relocação habitacional, quando se faz uso de generalizações, as possibilidades de incorrer em erros são maiores. Este foi um dos motivos que geraram dificuldades no caso do processo de relocação de FDF no Passo da Pátria gerida pelo Município de Natal.

\section{A experiência de relocação de FDF na comunidade Passo da Pátria, Natal/RN.}

O Passo da Pátria é uma AEIS, sendo composta por três comunidades: Pedra do Rosário, Passo da Pátria, Areado e Pantanal (figura 5).

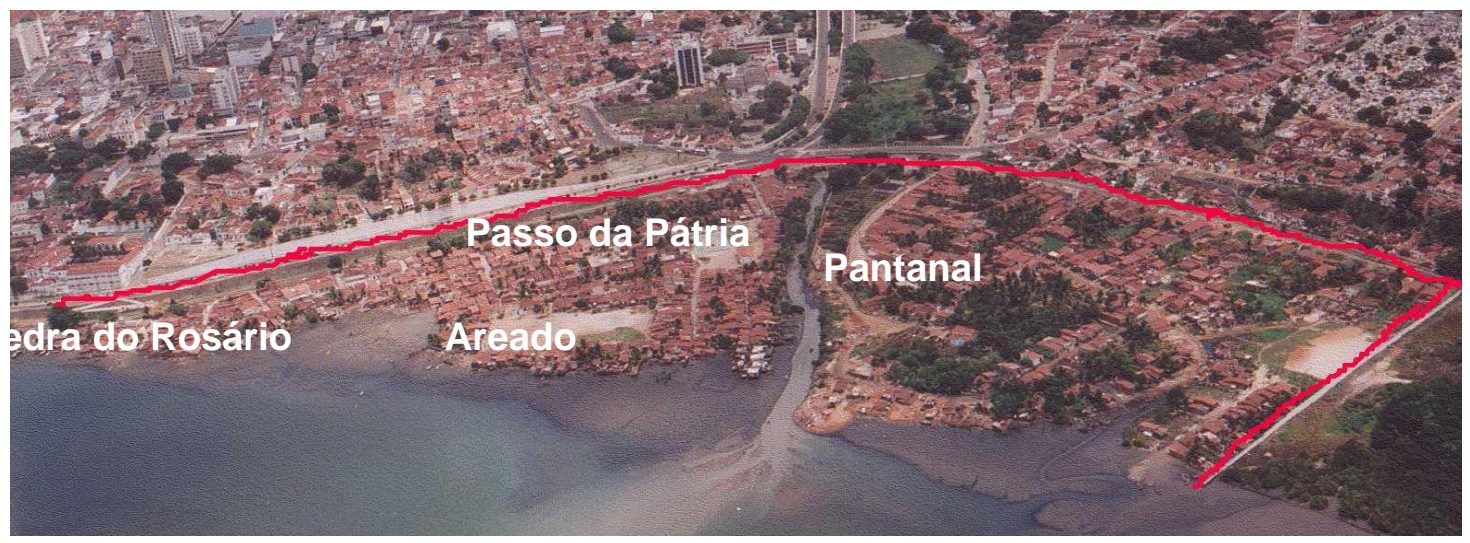

Figura 5: Vista superior Comunidade Passo da Pátria, Natal/RN.

Fonte: SEHARPE. Nota: Reelaborado pela autora.

O projeto de intervenção do governo municipal iniciou em 2002 e possui em sua problemática duas situações de ocupação em área de risco: casas construídas sobre palafitas, outras situadas na FDF ou as duas situações juntas. Esta última situação, e mais crítica, é recorrente na comunidade da Pedra do Rosário, onde a frente das casas volta-se para o trilho e os fundos sustentam-se por palafitas, sujeito tanto aos perigos do trem, quanto as inundações da maré (figura 6). Diante da confluência de riscos, esta faixa foi à escolhida para iniciar os trabalhos de reassentamento.
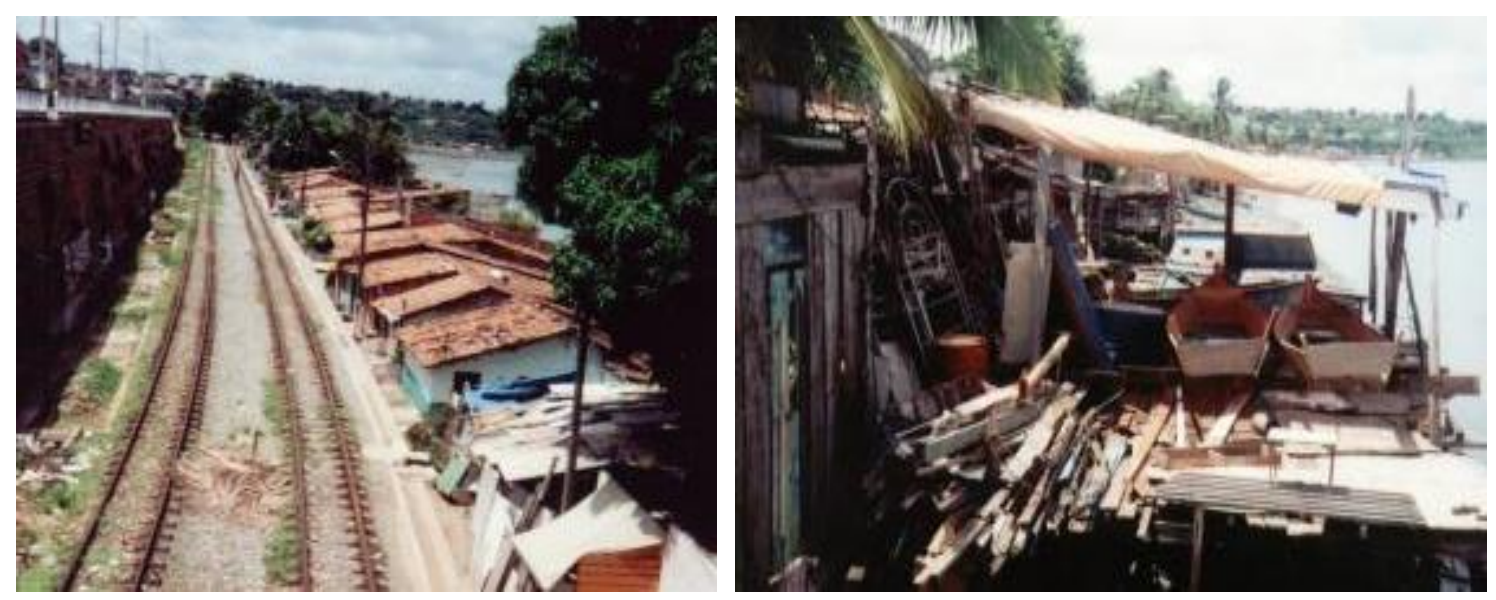

Figura 6: (a) Casas da Pedra do Rosário entre o trilho e a maré, (b) Fundos das Casas da Pedra do Rosário. Fonte: SEHARPE. 


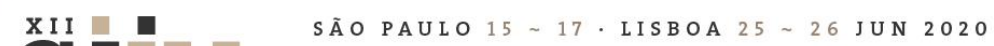 \\ Seminário Internacional de \\ Seminario Internacional de Investigação em Urbanismo Investigación en Urbanismo}

Segundo interpretação dos relatos ${ }^{6}$, não houve participação da comunidade nas decisões da proposta projetual das unidades habitacionais. As reuniões comunitárias ocorreram com o intuito de apresentação do programa de intervenção, para negociar a relocação com as decisões projetuais pré-definidas.

Uma, dessas predefinições, era um único projeto de unidade habitacional oferecido para atender todos os casos. Outra foi à escolha do programa em destinar a construção das casas por construtoras licitadas, sendo esta uma determinação inicial, também não discutida. Inicialmente os encontros ocorreram para conscientizar sobre a irregularidade da terra, dos riscos e apresentar as propostas.

Seguindo esta sistemática, as ações do projeto incorreu em alguns problemas durante as negociações, o que influenciou na formação dos seguintes grupos analíticos.

O primeiro grupo é formado pelos moradores que aceitaram sair da beira do trilho por uma casa do projeto na comunidade. A maioria deles estava em barracos ameaçados entre a maré e o trem na situação mais crítica encontrada. Por este motivo, estavam predispostos a aceitar quaisquer benefícios que permitisse condição mínima de moradia e quando questionados demonstram-se satisfeitos com a mudança.

O segundo é composto de pessoas que aceitaram a relocação, mas não viviam em barracos, possuíam casas e algumas com metragem maior que a oferecida pelo projeto. Nestes casos, a insatisfação é mais identificada devido à má qualidade da unidade habitacional oferecida pelo projeto tanto em termos de dimensões quanto na qualidade dos materiais.

O terceiro é composto pelas pessoas que esperam indenização, a qual é demorada e em muitos casos não atende as expectativas dos moradores. A avaliação é feita apenas com fatores objetivos como a metragem total, padrão construtivo e irregularidade da posse desconsiderando valores subjetivos como: a história do morador com a construção da casa, sua melhoria de alguns materiais de revestimento e a relação de vizinhança.

Como o valor das indenizações oferecidas ${ }^{7}$ foi inferior às expectativas, esta opção foi uma das mais ineficazes. Além disso, não proporcionaram a compra de uma casa equivalente nas proximidades, restando à escolha de aceitar a casa do projeto, também, reprovada pelos motivos já mencionados.

Por isso, das 54 famílias cadastradas na Pedra do Rosário para serem retiradas da proximidade com o trem, apenas 19 fizeram acordo e alguns entraram na justiça para garantir o seu direito de permanência.

Logo, infere-se que o processo de restabelecimento da faixa não edificante e FDF é mais aceitável, se oferecidas unidades habitacionais equivalentes às melhorias conquistadas por cada grupo a ser relocado ou reassentado.

Apesar de todos esses aspectos indicarem uma resistência das famílias em FDF aos processos de relocação e reassentamento, é consenso do poder judiciário o restabelecimento de ambas as faixas de segurança. Em Natal/RN ação do Ministério Público Federal (MPF), transitado em julgado, responsabiliza a União Federal, a CBTU, o Governo do Estado, o Departamento Nacional de Infraestrutura de Transportes e o Município de

\footnotetext{
6 Entrevistas realizadas com: MONIQUe LARISSA SILVA CUNHA, VIOLETA RIBEIRO DE QUEVEDO e Roxane DE LIMA RIBEIRO (assistentes sociais do projeto) E COM SEVERINA MARIA DAVI, AURILENE MARIA dOS SANTOS, SILVANA CRISTINA DA SILVA (moradores), EM NOVEMBRO DE 2008.

7 Relatos dos Trabalhadores.
} 


\section{SÃOPAULO15 17 LISBOA $25 \sim 26$ JUN 2020}

Natal pelo cuidado com a manutenção e restabelecimento da Faixa de Domínio de Ferrovia (MARINHO, 2012).

\section{Considerações Finais}

Depreende-se, a partir dos casos sucintamente mencionados sobre a problemática em território de Domínio Ferroviário no Brasil, que existe uma ineficiência no restabelecimento da FDF. Algo justificado, em parte, pela dimensão territorial e social que o fenômeno atinge. Na grande maioria dos casos, os impactos de uma ação sem o devido planejamento, desconsiderando a inserção destas populações no espaço urbano pelo tempo de ocupação, pode somente mudar o problema. Sana-se o risco, mas adquire-se outros problemas ao lhes destituir o direito à cidade quando conduzidos para outra porção da cidade sem a mesma qualidade.

Diante do discorrido, é evidente apontar a especificidade dos processos de relocação em FDF e a maneira como estão e serão conduzidos para melhor orientar os investimentos públicos em Habitação de Interesse Social. Isto, para que não incorramos em erros do passado sob outras formas de atuação, mas com a mesma essência das remoções, desconsiderando os ganhos sociais de direitos adquiridos pelas lutas sociais representadas no Estatuto das Cidades.

Não é mais concebível, pelos aprendizados históricos assimilados, utilizar somente o risco como justificativa para deslocamento de famílias no território urbano, sem estudar e propor alternativas de intervenção viáveis do ponto de vista técnico e econômico capazes de representar os anseios sociais envolvidos.

\section{BIBLIOGRAFIA}

ALCÂNTARA, C.; DIÓGENES, M. Relatório Final a Guarita e o Trem: uma disputa pelo espaço. Universidade Federal do Rio Grande do Norte - Centro de Tecnologia Arquitetura e Urbanismo. Natal/ RN 2008. 51p.

BRASIL. Lei no 13.913, de 25 de novembro de 2019. Altera a Lei oㅡ 6.766, de 19 de dezembro de 1979, para assegurar o direito de permanência de edificações na faixa não edificável contígua às faixas de domínio... Brasília.

BRASIL. Lei oㅜ 10.257, 10 DE JULHO DE 2001. Estatuto da Cidade. Regulamenta os arts. 182 e 183 da Constituição Federal, estabelece diretrizes gerais da política urbana.

BRASIL. Ministério das Cidades/Aliança de Cidades. Ações Integradas de Urbanização de Assentamentos Precários - Edição Bilíngue. 1. ed. Brasília/São Paulo: Ministério das Cidades, 2010.

BONDUKI, N. Origens da habitação social no Brasil: Arquitetura Moderna, Lei do Inquilinato e Difusão da Casa Própria. 2.ed. São Paulo: Estação Liberdade: FAPESP: 1998.

CBTU. Superintendência de Trens Urbanos de Natal/RN. História da Ferrovia. Natal, 1997.

DIÓGENES, M. Plano de Estruturação Urbana no entorno de ferrovias: uma proposta participativa para a Guarita. Universidade Federal do Rio Grande do Norte - Centro de Tecnologia - Curso de Arquitetura e Urbanismo. Natal/ RN: 2009. 157 p. - (2014): Reassentamentos de famílias em projetos de habitação social: avaliação de procedimentos e resultados no projeto Planalto II, Natal /RN. Natal/ RN. 159 p. --

FERREIRA, G. Produção habitacional, agentes e território: uma análise do PMCMV na RMNatal (2009-2014). 2016. 303f. Tese (Doutorado em Arquitetura e Urbanismos) - Programa de Pós-graduação em Arquitetura e Urbanismo. Universidade Federal do Rio Grande do Norte, Natal, 2016. 


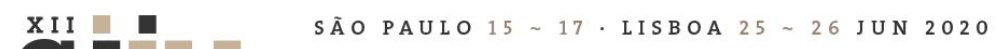

Seminário Internacional de Investigação em Urbanismo

Seminario Internacional de Investigación en Urbanismo

HALL, P. Cidades do amanhã. São Paulo: Perspectiva, 1988.

LIMA, R. Faixa de Domínio e Assuntos Correlatos. Despacho Jurídico CBTU da Assistente Técnico I/SUJUR. Rio de Janeiro, 08 de maio de 2006. Disponível em:<http://www.cbtu.gov.br/estudos/gtdu/materialtec/despacho.htm> Acesso em: 26/01/2012. Rio de Janeiro, 2006.

MINISTÉRIO DAS CIDADES. Secretaria Nacional de Habitação. Secretaria Nacional de Saneamento Ambiental. Programa de Aceleração do Crescimento - PAC - MANUAL DE INSTRUÇÕES Projetos Prioritários de Investimentos - PPI. Intervenções em Favelas. Brasília, 2007-2010. Disponível em: < http://www.cidades.gov.br/index.php/programas-e-acoes>. Acesso em: 03/08/2011. Brasília, 2007-2010.

MINISTÉRIO DAS CIDADES. Secretaria Nacional de Habitação. Política Nacional de Habitação. Brasília: Nov., 2004.

VARGAS, M. Construção social da moradia de risco: a experiência de Juiz de Fora (MG). R. B. ESTUDOS URBANOS E REGIONAIS, São Paulo, V. 8, N. 1, p.59-78, MAIO. 2006. Disponível em: < http://www.anpur.org.br/revistas/ANPUR_v8n1.pdf> Acesso em: 03/10/2011. São Paulo, 2006.

Viagens de trem para Ceará Mirim serão retomadas segunda-feira. Tribuna do Norte. Natal, 10 de Outubro de 2008. Disponível em: < http://tribunadonorte.com.br/noticia/viagens-de-trem-para-ceara-mirim-seraoretomadas-segunda-feira/89881 > Acesso em: 18/01/2012. Natal, 2008.

VILLAÇA, F. Espaço Intraurbano no Brasil. São Paulo: FAPESP/Studio Nobel,1998. 